\title{
Crítica literária e sociologia no Brasil e na Argentina*
}

Luiz Jackson e Alejandro Blanco

Embora os processos de modernização da crítica literária no Brasil e na Argentina inscrevam-se em tradiçôes intelectuais, mercados de bens culturais e organizaçôes acadêmicas distintas, algumas circunstâncias comuns permitem aproximá-los. Entre estas, enfatizaremos neste texto o fato de que, nos dois casos e quase ao mesmo tempo, a crítica literária aproximou-se da sociologia, esforçando-se por obter um estatuto mais científico do que detinha até, aproximadamente, a primeira metade do século XX.

De fato, entre as décadas de 1950 e 1960, os polos mais dinâmicos da crítica literária nos dois países renovaram-se mediante a incorporação de instrumentos teóricos oriundos da sociologia, apesar da tensão existente entre tais orientações e as que defendiam a análise estética do texto literário ${ }^{1}$. Além disso, as duas disciplinas enfrentaram temáticas convergentes nesse período, relativas, sobretudo, aos problemas da formação e da modernização da sociedade e da cultura nos dois países. Em tal direção, nos dois lados dessas fronteiras disciplinares programas de pesquisa e estilos de trabalho inovadores (e ambiciosos) foram desenvolvidos. Se, na sociologia, Florestan Fernandes e Gino Germani foram as figuras proeminentes desse processo, constituindo-se, cada um em seu país, como a principal liderança intelectual e institucional dessas disciplinas, na crítica literária, um papel análogo foi
* Este texto faz parte de uma pesquisa em andamento, voltada à comparação entre os processos de fundação da sociologia no Brasil e na Argentina. Agradecemos a Heloisa Pontes, Sergio Miceli e Jorge Myers os comentários a uma versão preliminar e o estímulo à sua publicação. Uma segunda versão foi discutida em seminário com os colaboradores deste Dossiê, que nos ajudaram a afinar nosso argumento.

1. Certamente, houve também reivindicação de cientificidade por meio da análise estética. No caso argentino, pelos herdeiros da "escola" de Amado Alonso; no brasileiro, sobretudo, por Afrânio Coutinho, que tinha como referência o New Criticism. Neste texto, no entanto, a ênfase recai sobre os críticos que incorporaram (de maneira distinta) a sociologia como instrumento analítico. Isso explica a seleção de Adolfo Prieto e Antonio Candido como parâmetros para examinar a relação entre crítica literária e sociologia nos dois casos. 
desempenhado por Antonio Candido e Adolfo Prieto, respectivamente, no Brasil e na Argentina.

Essa afirmação não despertará dúvida em relação ao papel desempenhado por Antonio Candido no Brasil, mas sim, talvez, ao que logrou concretizar Adolfo Prieto na Argentina. De fato, a obra e a atividade intelectual de Antonio Candido foram crescentemente valorizadas nas últimas décadas do século XX e ainda mais à medida que este se distanciou das disputas e das polêmicas nas quais se envolveu e das críticas que recebeu até o final da década de 1980. Tal itinerário é revelador do sucesso do empreendimento acadêmico que levou a cabo. Esse projeto teve como suporte a sua prolongada atuação na universidade, especialmente na Faculdade de Filosofia, Ciências e Letras da Universidade de São Paulo (FFCL-USP) à frente da Cadeira de Teoria Literária e Literatura Comparada, depois de 1961, na qual reuniu um grupo destacado de professores e pesquisadores, alguns muito reconhecidos posteriormente, como Roberto Schwarz, Davi Arrigucci Jr. e Walnice Nogueira Galvão. No caso de Adolfo Prieto, apesar do alto nível e da abrangência da sua produção acadêmica, a avaliação de sua obra e da liderança intelectual que exerceu, embora tenha sido sempre favorável, nunca resultou numa consagração equivalente.

Quem mais se aproximou disso foi David Viñas, considerado até hoje pela maioria dos intérpretes o principal artífice do processo de renovação da crítica literária argentina entre as décadas de 1960 e 1980. Contudo, uma apreensão mais detida da carreira de Prieto (e das circunstâncias nas quais se desenvolveu), comparada com a de David Viñas e outras figuras destacadas da mesma geração - como Jaime Rest, Enrique Pezzoni e Noé Jitrik, entre outros -, revela que foi quem mais se empenhou (e logrou concretizar)

2. Publicada entre os anos de 1967 e 1968 e comercializada em bancas de jornal, a publicação era assim apresentada na contracapa de alguns de seus 59 números: "Todas as semanas ocorre uma nova entrega, que consta de um fascículo e um livro. Cada fascículo oferece um panorama completo de um autor ou de um período. Os fascículos em seu conjunto constituirão a 'História da literatura argentina' propriamente dita; os livros constituirão as 'Biblioteca Argentina Fundamental"'. numa reconstrução sistemática e ampliada da literatura argentina, não apenas por meio de sua obra individual, mas também pelos diversos projetos coletivos que dirigiu, destacando-se sua participação decisiva (concepção, redação de alguns textos e supervisão de quase todos os artigos redigidos para a obra) no projeto que originou uma das mais bem-sucedidas histórias da literatura argentina e que teria enorme impacto no desenvolvimento da crítica posterior: Capitulo: la historia de la literatura argentina ${ }^{2}$. Além disso, diferentemente de David Viñas, que se dedicou tanto à crítica literária, como à literatura propriamente dita e a outras formas de criação artística, Adolfo Prieto construiu toda sua carreira no interior da universidade, dedicando-se integralmente à realização de um programa de pesquisa (extremamente renovador no contexto em que surgiu), solidamente apoiado em instrumentos 
analíticos oriundos da sociologia e da psicanálise e menos interessado na avaliação estética dos textos. Tais aspectos justificam a ênfase conferida a esse autor no argumento desenvolvido neste artigo.

Um primeiro elemento para entender o insucesso relativo do programa de pesquisas liderado por Adolfo Prieto relaciona-se com a centralidade mais prolongada detida pela literatura no campo intelectual argentino durante o século XX, em relação ao caso brasileiro. Nessa configuração, até pelos menos o final dos anos de 1970, as posições dominantes do mundo literário eram ocupadas pelos próprios escritores e apenas secundariamente pelos críticos. Como contraponto, tipicamente, no Brasil, a crítica como atividade desenvolvida profissionalmente no interior da universidade e fora dela, nos principais jornais do país, impõe-se progressivamente, sobretudo, a partir de $1950^{3}$, como instância reconhecida de arbitragem da produção cultural e literária, o que aconteceria na Argentina mais ou menos trinta anos depois. Além disso, não apenas Adolfo Prieto, mas todo o grupo da revista Contorno teve que enfrentar uma tradição acadêmica muito prestigiosa na Faculdade de Filosofia y Letras (FFyL) da Universidade de Buenos Aires (UBA) - onde Prieto se formou, mas jamais lecionou -, tradição esta que fora estabelecida durante a permanência (1927-1946) do crítico espanhol Amado Alonso à frente do Instituto de Filologia e Literaturas Hispânicas, autor que enfatizava a análise interna dos textos literários. Isso talvez explique, aliás, o fato de nenhum dos críticos de Contorno ter ensinado na UBA. A inserção profissional deles nas décadas de 1950 e 1960 deu-se nas universidades menos prestigiosas do interior do país, o que certamente limitou o alcance dos projetos que tentaram desenvolver. Na USP, diferentemente, não se consolidou até o início dos anos de 1960 nenhuma corrente de análise predominante. De modo semelhante, nenhuma liderança acadêmica se impusera claramente até aquele momento no curso de Letras. Tais circunstâncias favoreceram o movimento de renovação encabeçado por Antonio Candido na Cadeira de Teoria Literária e Literatura Comparada da USP.

Trata-se de uma imagem mais ou menos generalizada na Argentina a de que a crítica teria precedido a literatura nesse país (cf. Perosio e Rivarola, 1980), pois suas primeiras expressões, surgidas no último quarto do século XIX, se deram num momento em que a literatura não havia ainda amadurecido como um sistema. De todo modo, algumas décadas antes do que
3. O crítico e historiador da literatura Afrânio Coutinho foi muito feliz ao caracterizar os anos de 1950 pela centralidade da crítica literária: "A década de 1950, na literatura brasileira, pode ser considerada como da crítica literária. É o momento em que se adquire a consciência exata do papel relevante da crítica em meio à criação literária e aos gêneros da literatura imaginativa, função de disciplina do espírito literário. Sem ser um gênero literário, mas uma atividade reflexiva de análise e julgamento da literatura, a crítica se aparenta com a filosofia e a ciência, embora não seja qualquer delas." (Coutinho, 1986, p.634). 
4. Certamente, Sur recrutou, como colaboradores, professores e pesquisadores como Francisco Romero, Amado Alonso, Raimundo Lida, Angel Battistessa e, mais tarde, Ana Maria Barrenechea, Enrique Pezzoni e Jaime Rest, porém a revista atuou mais como uma plataforma de promoção dos escritores do que de difusăo de trabalhos especializados (cf. King, 1989, pp. 114-115). no Brasil, o ensino de Letras foi institucionalizado academicamente com a criação da FFyL em 1896. Dois outros fatos devem ser mencionados por sua importância na constituição ulterior da crítica nesse país. O primeiro refere-se à criação da revista Nosotros (1907-1934, 1936-1943), o segundo liga-se à instituição da Cátedra de Literatura Argentina (1912) na FFyL, que seria dirigida por Ricardo Rojas. Além da universidade, de Nosotros e de outras revistas, a imprensa diária, principalmente no jornal La Nación, foi decisiva, não tanto para a gestação de uma crítica mais alentada, mas, sobretudo, para o desenvolvimento da crítica de circunstância, assim como para a profissionalização da atividade.

Talvez seja possível caracterizar Nosotros como uma revista de "críticos literários", se a ela contrapusermos a publicação que a sucedeu como eixo do campo intelectual argentino a partir da década de 1930, Sur, esta entendida, em contraponto, como uma revista de "escritores" ${ }^{4}$. Apesar de um pouco caricatural, essa talvez seja uma boa pista para entender uma das linhas de força que estruturaram a vida literária nesse país durante o século XX. Os fundadores de Nosotros e filhos da imigração maciça, Alfredo Bianchi e Roberto Giusti, eram jovens egressos da FFyL, com 25 e 20 anos, respectivamente. A revista tinha periodicidade mensal (foram publicados 390 números) e reunia colaboradores numerosos e provenientes de círculos sociais e intelectuais distintos.

Quase ao mesmo tempo, ou seja, ao longo das três primeiras décadas do século XX, e no interior da FFyL da UBA, prevalecia o intento de historiar a literatura argentina, por iniciativa direta de Ricardo Rojas, à frente da Cadeira de Literatura Argentina (a partir de 1912). Desse programa, nasceu a obra La literatura argentina:ensayo filosófico sobre la evolución de la cultura en el Plata, cujos volumes foram publicados entre 1917 e 1922, em sintonia com o clima do nacionalismo cultural que marcou o centenário. Essa direção inaugurada por Rojas teria continuidade imediata no Instituto de Literatura Argentina - que ele dirigiu -, e posterior, nas diversas reconstruções realizadas, especialmente as que dirigiram Rafael Arrieta, intitulada História de la literatura argentina (seis volumes, publicados entre 1958 e 1960), e Adolfo Prieto, Capitulo: historia de la literatura argentina. Igualmente é possível inscrever nessa tradição (apesar de seu caráter ensaístico e polemista) o livro Literatura nacional y realidad política (publicado em 1964), de David Viñas.

O efeito porventura mais agudo da organização acadêmica do ensino e da pesquisa em Letras derivou também de uma ação direta do próprio Ricardo Rojas, que concebeu e criou o Instituto de Filologia em 1923, momento em 
que dirigia a FFyL. A partir de contatos estabelecidos com o espanhol Ramón Menéndez Pidal, então diretor do Centro de Estudios Históricos de Madrid, organizou uma missão estrangeira, cujo principal representante seria Amado Alonso. Sua atuação prolongada à frente desse instituto implicou uma transformação profunda dos estudos literários na Argentina, doravante apoiados em métodos sofisticados de análise interna dos textos (cf. Barrenechea e Lois, 1989; Barrenechea, 1995/1996). Com a colaboração estreita do dominicano Pedro Henriquez Ureña, formou um grupo de pesquisadores destacados, como Angel Battistessa, Raimundo Lida, Enrique Anderson Imbert, Maria Rosa Lida de Malkiel, Raúl Hector Castagnino e Emilio Carilla, entre outros.

Do que já foi dito, é possível vislumbrar o quadro que resume o universo da crítica argentina na primeira metade do século XX. Apoiada na imprensa diária, nas revistas culturais e na universidade, embora essas três instâncias se relacionem intimamente, cada uma delas promove um tipo diferenciado de trabalho intelectual, definidos pelos condicionamentos impostos pelo sistema acadêmico, num caso, e pelos que regulam a vida cultural e literária propriamente dita, nos outros. No interior da universidade, como já indicado, duas tradições claramente diferenciadas se estabeleceram: uma voltada à história literária, outra estribada na filologia e na estilística. Fora da universidade, além da crítica regular nos jornais, as revistas divulgavam novidades e nucleavam o debate mais acalorado sobre a vida literária em curso. Mencionamos Nosotros, desafiada na década de 1920 pelas revistas de vanguarda e deslocada posteriormente por Sur. Nesta última, dominada por uma aristocracia social e literária, capitaneada por Victória Ocampo e Jorge Luis Borges, a crítica seria praticada, principalmente, pelos próprios escritores (como fizera Lugones anteriormente) ou por críticos afinados com a percepção daqueles que reivindicavam para si mesmos (e não para os críticos propriamente ditos) o papel de árbitros do mundo cultural'

A hegemonia cultural exercida pela revista Sur por mais de vinte anos começou a declinar nos anos de 1950, entre outros fatores, em função do clima político que envolveu a queda do peronismo (1955), desfazendo a relativa unidade da comunidade intelectual e artística que prevalecera desde 1946 até então. Nesse contexto, surgiram as revistas Centro (1951-1959) e Contorno (1953-1959). Embora a segunda tenha atraído maior atenção dos intérpretes e ficado marcada no imaginário intelectual como o núcleo de uma geração inovadora, a primeira foi igualmente importante naquele momento, tendo reunido, como órgão oficial do Centro de Estudantes da Faculdade de Filosofia e Letras da UBA, um contingente mais amplo de participantes
5. Os conhecidos desafios e burlas de Borges contra Ricardo Rojas, Américo Castro e Amado Alonso (a quem Borges considerava um pedante) são expressivos dessa disputa entre escritores e críticos em torno da autoridade de pronunciar-se sobre questôes literárias (cf. King, 1989). 
6. Ramón Alcalde, León Rozitchner, Juan José Sebreli, Adelaida Gigli, Adolfo Prieto, Noé Jitrik, Regina Gibaja, Oscar Masotta, Francisco J. Solero e Rodolfo Kusch. e de orientações intelectuais. Nessa direção, incorporou estudantes que não participaram de Contorno, mas que se projetariam mais tarde, como Jaime Rest (que seria professor da UBA) e Rodolfo Borello (que seria professor na Universidade Nacional de Cuyo, em Mendoza, entre 1956 e 1976). Ademais, participaram como organizadores ou como colaboradores na revista jovens estudantes que, na década seguinte, migrariam para a sociologia, então liderada por Gino Germani. Esse foi o caso de Eliseo Verón, Miguel Murmis, Celia Durruty, Darío Cantón e Regina Ribaja, entre outros. Vale a pena destacar o fato de que Adolfo Prieto participou mais ativamente em Centro do que em Contorno. Na primeira, integrou o conselho de redação desde 1953 e publicou três artigos, além de uma peça de teatro (cf. Prieto, 1952, 1953a, 1953b, 1953d). Na segunda, apenas apareceu no comitê de direção nos anos de 1957 e 1958, quando foram editados os dois Cuadernos de Contorno, e no ano de 1959, no último número $9 / 10$ da revista, no qual publicou uma resenha e um artigo político (cf. Prieto, 1953c, 1956b).

Idealizada pelos irmãos Ismael e David Viñas, Contorno foi uma derivação de Centro (quase todos seus integrantes participaram desta última). Integrada por um grupo mais restrito de colaboradores ${ }^{6}$, acentuou algumas tendências já presentes em Centro, interrogando o significado da literatura no país, propondo-lhe um novo cânone e questionando os critérios mobilizados pela crítica literária até então.

Durante a segunda metade da década de 1940, quase todo o grupo de Contorno estudou na FFyL, então sob intervenção peronista, quando muitos professores foram afastados (ou renunciaram) e substituídos. Tal fato implicou um deslocamento da vida intelectual para fora da universidade, para instituiçôes privadas como o Colégio Livre de Estudos Superiores e, em consequência, um declínio da qualidade do ensino universitário. No curso de Letras, especificamente, tal momento marcou a marginalização da estilística, perspectiva predominante desde o final dos anos 1920, quando o espanhol Amado Alonso assumiu a direção do Instituto de Filologia na UBA. Os membros de Contorno referem-se em entrevistas ao fato de que o mais atrativo de sua experiência universitária não era a sala de aula, mas a sociabilidade efervescente dos cafés e das livrarias situados no entorno da faculdade, na calle Viamonte e arredores (cf. Sebreli, 1987)

Proveniente de San Juan, Adolfo Prieto mudou-se para Buenos Aires no momento preciso dessa viragem, no ano de 1946. Ele tinha, então, 18 anos de idade e quase nenhum capital cultural. Seu pai era imigrante espanhol, aportado na Argentina em 1913, que, depois de trabalhar alguns anos na 
colheita de trigo em Córdoba, conseguiu montar uma pequena indústria de doces na cidade de San Juan, onde se casou com uma filha de imigrantes, também espanhóis. A decisão de estudar Letras não foi bem-recebida pelo pai, que, a contragosto e convencido pela esposa, sustentou financeiramente sua formação universitária. Sua origem provincial explica, provavelmente, a inserção marginal no grupo de Contorno e a opção posterior pela carreira acadêmica, à qual dedicou toda sua vida.

A relativa unidade programática da revista tinha como referência, em primeiro lugar, o fato de que todos os membros tinham mais ou menos a mesma idade (nasceram no final dos anos de 1920). Em segundo, conheceram-se e conviveram na faculdade, sobretudo, por meio da militância acadêmica e política no Centro de Estudiantes de Filosofia e Letras (CEFyL), que então assumia uma posição claramente antiperonista. A maioria deles começou a escrever e ganhou alguma experiência editorial na revista Centro, periódico oficial do CEFyL. Tais traços e experiências comuns, entretanto, revestiam diferenças sociais importantes certamente relacionadas com as subdivisões do grupo.

Tais subdivisões refletiam a expansão quantitativa do ingresso no ensino universitário durante o peronismo (1946-1955) e uma mudança significativa no recrutamento social dos estudantes da UBA e da FFyL, em particular. Entre 1947 e 1955, o ingresso universitário quase triplicou, de 51.272 a 143.542 matriculados (Warley e Mangone, 1984, p. 28). Em relação ao recrutamento social, Gino Germani registrou para o ano de 1956 uma abertura significativa do ensino superior para os setores "médios inferiores" e "populares". Na FFyL, um terço dos estudantes provinha destes últimos (cf. Germani, 1956).

Os irmãos Viñas eram os mais providos socialmente. Essa condição inscreveu neles disposições mais ousadas, relacionadas com a militância política e as aspiraçôes intelectuais do pai deles, advogado oriundo de uma família tradicional e estreitamente ligado ao governo de Hipólito Irigoyen nos anos de 1920. A morte precoce da mãe e outras circunstâncias adversas possivelmente os influenciariam a seguirem caminhos menos convencionais. Esse quadro vale, sobretudo, para David, que se arriscou de maneira bemsucedida nos domínios do ensaio crítico, da ficção e do cinema, entre as décadas de 1950 e 1960. Literatura argentina y realidad politica foi, apesar do êxito que alcançou no âmbito da crítica literária, apenas uma das direçôes que seguiu como artista e intelectual. De fato, antes da edição desse livro, ele já havia publicado nada menos do que seis romances: Cayó sobre su rostro 
7. Dar la cara seria adaptada para o cinema no mesmo ano da publicação do livro (direção de José Martinez Suárez), em 1962. David Viñas já havia escrito vários roteiros: em 1958, El jefe; em 1959, El candidato; em 1960, Sábado a la noche, cine (os três últimos com direção de Fernando Ayala).

8. A adesão dos três ao peronismo implicou um conflito com os irmãos Viñas e seu afastamento temporário da revista no final de 1954, quando foi publicado o número 4 de Contorno, dedicado a Martinez Estrada. em 1955, Los años despiadados em 1956, Un dios cotidiano em 1957, Los dueños de la tierra em 1958, Dar la cara em 1962 e Las malas costumbres em 1963. Cabe, ainda, destacar que o autor foi igualmente bem-sucedido como romancista, recebendo, em 1957, o Premio Gerchunoff por Un dios cotidiano e, em 1962, o Premio Nacional de Literatura por Dar la cara ${ }^{7}$. Não se deve estranhar, assim, o tom ensaístico de Literatura argentina y realidad política, nem a sensação que se tem à leitura de que o autor se esforça por inscrever-se na tradição que examina.

Esse contraponto indica uma característica do grupo de Contorno: sua heterogeneidade social, a qual propiciou destinos muito distintos aos seus criadores, após o final da empreitada coletiva. Juan José Sebreli e Oscar Masotta, por exemplo, pertenciam a famílias de imigrantes de classe média baixa, radicadas em Buenos Aires, que nunca lograram alcançar alguma prosperidade econômica (cf. Sebreli, 1987; Correas, 2007). Ambos deixaram inconcluso o curso de Letras e orientaram sua atividade intelectual posterior como autodidatas e ensaístas, em direções alternativas, abandonando a crítica literária, que haviam cultivado até então e que resultou, respectivamente, nos livros Martinez Estrada: una rebelión inútil, de 1960, e Sexo y traición en Roberto Arlt, de 1965. De algum modo, nesses dois casos, as privaçóes econômicas e sociais enfrentadas na infância estiveram relacionadas não apenas com as iniciativas intelectuais inovadoras que empreenderam na década de 1960, mas também com a atitude transgressora que assumiram como estilo de vida. Sebreli e Carlos Correas, outro membro do grupo, formavam, juntamente com Oscar Masotta, um subgrupo dentro de Contorno, conhecido pela adesão ao existencialismo sartreano, pela aproximação política remota ao peronismo $^{8}$ e pela boêmia.

Como dissemos, a opção pela carreira acadêmica propriamente dita foi abraçada no grupo, sobretudo, por Adolfo Prieto. Esse foi o caso, também, de Noé Jitrik (1928) que assumiu a Cátedra de Literatura Argentina na Universidade Nacional de Córdoba em 1960, onde permaneceu até 1966. Prieto terminou a graduação em Letras no ano de 1951, iniciando imediatamente sua tese de doutorado, sob a orientação de Raúl Cortina, num momento em que realizar a pós-graduação era incomum. Obteve o título de doutor em 1953 com o trabalho El sentimiento de la muerte a través de la literatura española (siglos XIVyXV). Este seria o seu único trabalho de vulto dedicado à literatura estrangeira e também o que mais se aproximou da tradição da estilística, predominante na UBA desde a chegada de Amado Alonso. São razões possíveis dessa escolha temática, além da origem espanhola de sua 
família, a pouca importância acadêmica que se atribuía, então, à literatura argentina e a familiaridade do autor com a literatura espanhola, devida ao prestígio dessa literatura no interior da faculdade. Ainda que sua obra posterior fosse dedicada inteiramente à literatura argentina, em sua tese, Prieto assumiu diante dos textos literários espanhóis uma mesma atitude, diríamos sociológica, que ele aprofundaria posteriormente?

Em 1954, publicou seu primeiro livro, o polêmico Borges y la nueva generación, que trazia uma análise extremamente dura (e negativa) sobre o escritor que já nesse momento era a figura central e mais consagrada da literatura argentina. Essa atitude ousada e mesmo temerária inseriu Adolfo Prieto na cena literária argentina abruptamente, tendo, provavelmente, mais o prejudicado do que o favorecido. De todo modo, o livro constituiu-se como uma das "marcas" de sua geração, ao romper a aura sagrada que revestia fortemente o mundo literário naquele momento, reivindicando para a crítica (e para si mesmo) uma posição mais autônoma e determinante em relação à que detinha até então. Isso se desprende da parte do livro, anteriormente publicada na revista Centro (Prieto, 1953c), na qual o autor acusa Borges de praticar uma "crítica impressionista", "arbitrária” e "hedonista”; voltada para aspectos laterais das obras e não para sua totalidade, como deveria fazer uma "crítica objetiva". O texto analisado seria para aquela apenas um pretexto, um meio, e não um fim, como para a última. Dessa maneira, Prieto defendia o papel de árbitros do campo literário para os críticos e não para os próprios literatos.

Seu próximo livro, Sociologia do público argentino (publicado em 1956), revela de maneira inequívoca a afinidade do crítico com a sociologia, disciplina que vinha ganhando legitimidade no campo acadêmico, sobretudo em função das iniciativas capitaneadas por Gino Germani. A obra apresentou uma abordagem inédita sobre o público leitor, documentada por uma pesquisa empírica (quase desconhecida) realizada pelo sociólogo ítalo-argentino no Instituto de Sociologia em meados dos anos de 1940, sobre o consumo cultural da classe média portenha. O livro definiu o enquadramento básico de seu projeto intelectual, que encarou sempre o fenômeno literário como um sistema relacional, excluindo qualquer ideia de transcendência do fato literário de seu esquema interpretativo ${ }^{10}$.

Depois da publicação desses livros e de ensinar literatura por alguns anos no ensino secundário (o que conseguiu por intermédio de Raúl Castagnino, que havia sido seu professor na UBA), foi convidado em 1956 a lecionar literatura espanhola na Universidade Nacional do Litoral, em Rosario. Der-

\footnotetext{
9. Essa continuidade foi notada por Rodolfo Borello: "mais que a pura compreensão estética e literária, afincada nas formas, no estilo ou na língua, o crítico estava interessado em descobrir que tipo de homem havia escrito aquelas páginas, que motivaçôes sócio-históricas e psicológicas o explicavam. Atrás de versos a primeira vista circunstanciais, de crônicas esquecidas, de relatos cheios de recursos retóricos, Prieto perseguia as ideias, os sentimentos nacionais, o horizonte de valores que lhes davam sentido" (1967, p.133).
}

10. Essas mesmas preocupações sobre o público leitor reaparecem em Prieto (1988), formuladas com instrumentos analíticos mais sofisticados e fundamentada em pesquisa rigorosa, representando a concretização de um longo itinerário que indica a persistência de certas linhas de pesquisa no conjunto de sua obra. 
11. Oscar V. Grandov, Hebe Monges, Gladys Marcón, Noemí Ulla, Laura V. Milano, Gladys L. Ramat, Ada M. Cresta, Ana M. Deforel, Nélida M. Lanteri, Elena C. Carrero, Lucrecia Castagnino, Gladys S. Onega, Clotilde Gaña e Ada R. M. Donato. rotado no concurso realizado no final desse mesmo ano, regressou a Buenos Aires e, em 1957 - quando se casou -, atendendo a novo convite, assumiu pela primeira vez uma Cátedra de Literatura Argentina, dessa vez na Universidade Nacional de Córdoba. Em 1958, transferiu-se para a Universidade Nacional de Cuyo, em Mendoza, onde estava seu antigo colega de graduação e amigo íntimo Rodolfo Borello. Seu périplo nas universidades do interior do país culminou com seu estabelecimento prolongado, novamente em Rosario, de 1959 a 1966. Já no primeiro ano de sua atuação na Faculdade de Filosofia e Letras da Universidade Nacional do Litoral, nota-se a sua intenção de formar um grupo de pesquisadores, a partir de um seminário organizado sobre o impacto do rosismo na literatura argentina. Dessa experiência resultou um livro coletivo, Proyección del rosismo en la literatura argentina (publicado em 1959), redigido por estudantes ${ }^{11}$ sob a orientação cuidadosa de Prieto, que escreveu a introdução. Os autores perscrutaram no interior de diversos registros literários da época - romance, conto, poesia, jornalismo, teatro e literatura autobiográfica - as formas de inscrição social dos conflitos derivados da experiência do governo de Rosas e de sua dissolução. De outro seminário realizado em 1962, que visava traçar um quadro da crítica literária nacional e do qual participaram alunos e ex-alunos da faculdade, originou-se o livro Encuesta: la crítica literária en la Argentina (publicado em 1963). A obra reuniu depoimentos de dezenove críticos literários do país, que responderam a um mesmo conjunto de questôes, visando esclarecer as condições concretas que orientavam essa atividade como profissão predominante ou secundária, as relações estabelecidas com os escritores e o público, as linhagens teóricas predominantes e os meios de difusão existentes.

As duas iniciativas podem ser avaliadas como etapas de um projeto acadêmico de longa duração que Adolfo Prieto pretendia concretizar, inspirado por uma visão sintonizada com o processo de modernização universitária que também afetava outras disciplinas. O itinerário descrito é revelador, também, de um aspecto (ecológico) curioso do processo de inovação das disciplinas humanísticas (e sociais) no contexto da reforma universitária do pós-peronismo. Enquanto o polo moderno da sociologia, liderado por Germani, se assentou em Buenos Aires, centro do sistema acadêmico, na crítica literária ocorreu o contrário, sua modernização teve lugar na periferia do sistema. Como se sabe, entretanto, tais empreendimentos seriam abortados pelo golpe militar de 1966. Adolfo Prieto avaliou essa experiência nos seguintes termos: 
Ao cabo de cinco anos já era possível vislumbrar um grupo de estudiosos verdadeiramente interessantes, uma dezena de jovens profissionais que podiam integrar-se à universidade como docentes e pesquisadores com pleno direito. A maioria daqueles jovens de então está hoje dispersa nos quatro pontos cardeais do país e do mundo. O golpe militar e os sucessivos desencontros e calamidades sofridas pela universidade argentina oferecem a moral desencarnada do relato. Nenhuma política cultural ditada e implementada pela universidade desde seu próprio âmbito, ou ainda mais longe, nenhuma universidade pode sobreviver às ansiedades e à insegurança radical da sociedade à qual pertence $(1982$, p. 8).

Foi durante esses anos rosarinos que o autor redigiu e publicou, em 1962 pela Universidade Nacional do Litoral, sua obra mais importante desse período, La literatura autobiográfica, que, por seu caráter inaugural e alcance interpretativo, seria considerada uma referência obrigatória para o estudo do memorialismo na Argentina. O livro destaca a importância, até então não reconhecida, do gênero autobiográfico no conjunto dessa literatura nacional durante o século XIX e oferece ao leitor uma perspectiva inusitada para compreender as lógicas sociais que estruturaram a vida intelectual no país após a independência (que se iniciou com a Revolução de Maio em 1810). Nesse sentido, é, ao mesmo tempo, uma história de um gênero aparentemente secundário da literatura argentina e uma genealogia de suas elites políticas e intelectuais.

A recepção imediata desse trabalho, é importante destacar, foi muito favorável. O crítico argentino Alfredo Roggiano, quando lecionava na Universidade de Pittsburgh (Estados Unidos), escreveu uma resenha muito elogiosa na Hispanic American Historical Review, qualificando o livro como “o primeiro estudo orgânico da literatura autobiográfica argentina”, e a concluiu com um elogio explícito ao trabalho, afirmando a abrangência deste: "Livro de extraordinária lucidez, verdadeira radiografia do homem argentino, das classes dirigentes do país e das camadas mais profundas da história política, econômica, social e cultural da Argentina” (Roggiano, 1964, p. 662). Jaime Rest, então professor adjunto da Cadeira de Literatura Inglesa e Norte-Americana na FFyL da UBA - cujo titular era Jorge Luis Borges -, também resenhou o livro positivamente, num texto longo e detalhado, destacando a descoberta notável realizada por Prieto, ao perceber a importância "dessa espécie narrativa no interior da literatura argentina”. O resenhista afirmou ainda que, afastando o impressionismo que predominava na crítica argentina daquele momento, o livro revelava uma atitude analítica 
diferente: "o trabalho de Prieto merece a mais cálida aprovação como uma das principais contribuições recentes à compreensão da literatura argentina. Isso se explica pela análise séria que realiza e na qual se percebe um esforço para superar nossas habituais improvisações de crítica impressionista, com o objetivo de substituí-las por critérios mais objetivos e disciplinados" (Rest, 1963, p. 336).

Em ocasião da segunda ediçãao do livro, lançada em 1966 pela editora Jorge Alvarez, Rodolfo Borello escreveu um artigo extenso que revisava sistematicamente toda a obra de Adolfo Prieto até aquele momento e o definia como o principal crítico de sua geração: "Essa relação entre literatura e sociedade, entre literatura e personalidade, entre literatura e história, caracterizará para sempre suas obras e o constituirá no mais brilhante crítico de sua geração" (Borello, 1967, p. 134). A respeito desse artigo, não se pode negligenciar a amizade e o projeto comum que vinculavam os dois críticos desde que se conheceram como estudantes na UBA, o que conferia ao mesmo certo tom programático e deixava entrever a consciência que tinham a respeito do empreendimento que estavam realizando, sobretudo Prieto em Rosario, mas também secundariamente Borello na Universidad de Cuyo, em Mendoza. Como Pietro, Borello era de origem provinciana, nasceu em Catamarca em 1930, e ingressou no curso de Letras na FFyL na segunda metade da década de 1940. Foram apresentados pela namorada de Borello, Alicia (não sabemos seu sobrenome), de quem Prieto era colega de turma na UBA. Tornaram-se amigos e depois parceiros em vários momentos, a começar pela participação de ambos em Centro. Defendeu o doutorado na Universidad Complutense de Madrid. Entre 1956 e 1976, foi professor de literatura espanhola e argentina na Faculdade de Filosofia e Letras na Universidade Nacional de Cuyo. Borello dirigiu a Revista Argentina e Iberoamericana, na qual publicou uma versão reduzida da tese de doutorado de Adolfo Prieto. No final dos anos de 1950, Prieto lecionou em Mendoza, convidado por Borello. Como "supervisor" de Capitulo, Prieto encomendou a Borello a redação de três fascículos da coleção, um deles dedicado ao ensaio e outro, à crítica moderna.

Por fim, o importante crítico uruguaio Carlos Real de Azúa elogiou enfaticamente o livro de Prieto, em um artigo sobre o memorialismo uruguaio, publicado na versão uruguaia de Capítulo, lamentando que "faltava no Uruguai um estudo similar ao esplendido de Adolfo Prieto sobre $L a$ literatura autobiográfica argentina" (Azúa, 1968, pp. 3-4).

A origem de La literatura autobiográfica relaciona-se com a pesquisa anterior sobre o impacto do rosismo na literatura, durante a qual, provavelmente 
se dera conta da relevância desse material e do rendimento analítico que propiciava, uma vez que seu interesse teórico residia, sobretudo, no estudo da literatura como um fato social. Essa intenção é explicitada na epígrafe do trabalho, uma passagem de Mannheim ([1951]* 1972), que enfatiza a importância dos registros autobiográficos como meio de acesso às lógicas sociais estruturantes das personalidades e das funções desempenhadas por esse tipo de literatura nas conjunturas históricas abrangentes.

A menção a Mannheim - como outras tantas citações a Erich Fromm, Ralph Linton, Abraham Kardiner, Karen Horney, Mikel Dufreene, Wright Mills, Gilberto Freyre que figuram, sobretudo, na introdução teórica do livro - revela a importância que teve no campo intelectual argentino o movimento editorial impulsionado, desde meados da década de 1940, por novas editoras especializadas em ciências sociais, como a mexicana Fondo de Cultura Económica e a argentina Paidós. O espanhol José Medina Echavarría, no México, e Gino Germani, na Argentina, estiveram à frente dessas iniciativas, que tiveram enorme impacto no processo de institucionalização da sociologia, especialmente no caso que estamos examinando. De fato, a relativa marginalidade dessa disciplina no interior do sistema acadêmico até a segunda metade dos anos de 1950, foi compensada por tais empreendimentos, o que permite compreender a incorporação por Prieto de um ponto de vista sociológico nesse trabalho específico, mas também no restante de sua obra. Cabe dizer que essa tomada de posição pelo autor cumpria uma função dupla: contra a crítica estilística conectava a literatura com o mundo social e político, contra o ensaísmo e a crítica impressionista reivindicava cientificidade.

La literatura autobiográfica argentina representou uma importante inflexão no interior da tradição da crítica literária desse país, articulando a análise textual ao exame dos condicionantes sociais e políticos da vida literária. Especificamente, relacionou as diversas variantes da autobiografia às transformaçôes sociais e políticas que se seguiram à Revolução de Maio. Por meio dessa forma argumentativa, o trabalho sintetiza um programa de pesquisa em sociologia da literatura que recobre toda a sua produção intelectual e que teria importante continuidade na principal vertente da crítica literária argentina das últimas décadas, sobretudo nas obras de Beatriz Sarlo e Carlos Altamirano.

$\mathrm{O}$ itinerário descrito demonstra o investimento realizado por Adolfo Prieto entre os anos de 1950 e 1960, período no qual ele formou e liderou um grupo destacado de pesquisadores, dirigiu, na Universidade Nacional
* A data entre colchetes refere-se à edição original da obra. Ela é indicada na primeira vez que a obra é citada. Nas demais, indicase somente a edição utilizada pelo autor (N.E.). 
do Litoral, a Faculdade de Filosofia e Letras, o Instituto de Letras e o Boletim de Literatura Hispânicas e publicou uma tese de doutorado e dez outros livros (Borges y la nueva generación, Sociología del público argentino, Proyección del rosismo en la literatura argentina, La literatura autobiográfica argentina, Encuesta, Antología de Boedo y Florida, El periódico Martín Fierro, Literatura y subdesarrollo, Diccionario básico de literatura argentina, Estudios de literatura argentina). Nesse período, Pietro encontraria condiçōes favoráveis no contexto da modernização universitária em curso desde o final do peronismo e que teve como expressões mais visíveis nas ciências humanas os projetos acadêmicos de Gino Germani na sociologia e de José Luis Romero na história, intelectuais associados em alguns empreendimentos decisivos para a renovação das duas disciplinas. Como já foi dito, entretanto, tal processo foi abortado pelo golpe militar de 1966, que conduziu Ongania ao poder. A sociologia e a história refugiaram-se em instituições privadas, principalmente no Instituto Di Tella, que acolheu pesquisadores afastados da universidade. No caso da crítica literária, foram também iniciativas privadas que permitiram certo grau de continuidade aos distintos projetos intelectuais gestados no interior das universidades do país. A principal dessas iniciativas teve lugar no Centro Editor da América Latina - editora fundada por Boris Spivacov em seguida ao golpe -, que promoveu a realização de Capitulo. Idealizada pelo editor, essa obra teria a condução intelectual de Adolfo Prieto, oficialmente o "supervisor" dos números encomendados aos colaboradores convidados (alguns já experientes, outros jovens egressos das universidades que depois se destacariam). Pensada para um público amplo de leitores não especializados, essa terceira das principais histórias da literatura argentina acabou convertendo-se em ponto de referência obrigatório e fonte de muitas hipóteses que orientaram a crítica e a história da literatura subsequentes. O conjunto dessa história social da literatura argentina, não obstante o fato de ter sido formada por textos redigidos por um numeroso grupo de autores, revela uma unidade significativa, que nos parece resultar de uma concepção muito bem-informada e planejada da seleção criteriosa dos colaboradores, da orientação que lhes era dada e da revisão dos textos.

Depois de Capitulo, sobretudo após o início da ditadura militar de 1976, a trajetória de Adolfo Prieto sofreu uma forte inflexão relacionada com sua emigração aos Estados Unidos, onde lecionou por cerca de quinze anos. A publicação de El discurso criollista en la formación de la Argentina moderna no ano de 1988 interromperia um período de isolamento intelectual, já que 
o livro foi muito bem-recebido na Argentina. Não obstante, sua trajetória anterior não foi ainda devidamente aquilatada.

A esse respeito e, embora as circunstâncias políticas dos anos de 1970 estejam diretamente relacionadas com seu afastamento da cena intelectual e literária argentina até o final da década seguinte, esse desfecho desfavorável da primeira parte de seu itinerário intelectual explica-se, também, pela dinâmica prevalecente nessa cena até meados dos anos de 1980. Como indicado, desde o começo do século XX, sobretudo em função da presença dos imigrantes, da criação das universidades modernas no final do século XIX, da profissionalização das atividades intelectuais, o mundo cultural argentino viu-se polarizado entre os literatos propriamente ditos, oriundos das famílias tradicionais, e os intelectuais egressos das universidades, frequentemente filhos da imigração. Essa polarização expressou-se nas disputas entre os escritores e os críticos literários, desde o deslocamento de Nosotros (críticos) por Sur (literatos) nos anos de 1930, mas também no desafio lançado pelos jovens críticos de Contorno aos escritores estabelecidos em Sur e no jornal La Nación nos anos de 1950. O intento de Prieto de estabelecer uma nova forma de interrogação do fenômeno literário por meio de um programa de pesquisa em sociologia da literatura não poderia legitimar-se plenamente nesse contexto, no qual a literatura ainda era o fiel da balança.

Era muito diferente a disposição das peças do jogo cultural e acadêmico no Brasil quando Antonio Candido reivindicou indiretamente para si o papel de crítico literário "científico", em meados dos anos de 1940, ou, mais precisamente, no ano de 1945, na tese que escreveu sobre Silvio Romero para concorrer à Cátedra de Literatura Brasileira da USP (cf. Candido, [1945] 1988). Justamente nesse ano, antes da realização do concurso, a morte de Mário de Andrade sinalizava o fim de uma era, na qual a literatura havia ocupado o centro da vida intelectual e artística brasileira. Depois dele, que desempenhou papéis variados (cf. Miceli, 2009), todos derivados de sua atuação como escritor, a diferenciação progressiva desse universo privaria os literatos da possibilidade de erigirem-se em árbitros da produção simbólica erudita. Dito de outro modo, as funções do escritor e do crítico tornavam-se cada vez mais inconciliáveis, apesar das figuras que ainda transitariam nas duas esferas. Por isso mesmo, o significado que teve em São Paulo a criação da revista Clima, por um grupo de estudantes 
12. Esta parte do trabalho apoiase diretamente em Pontes (1998). Ver também Pontes (2011).

13. A respeito, a dedicatória "À memória de Mário de Andrade" feita por Antonio Candido na segunda edição (lançada em 1963) de seu primeiro trabalho de especialização, Introdução ao método crítico de Silvio Romero (de 1945), é muito significativa. oriundos das primeiras turmas dos cursos de filosofia e de ciências sociais da FFCL-USP foi muito diferente do que tiveram as revistas Centro e Contorno em Buenos Aires. Nestas, os jovens críticos desafiaram os escritores de Sur, sem obter deles qualquer sinal de reconhecimento, nem mesmo jocoso, como o que se percebe no apelido de "chato-boys" atribuído por Oswald de Andrade ao grupo liderado por Antonio Candido na revista Clima. Mas a legitimação desta não veio apenas de fora, estava inscrita na própria revista. Cabe mencionar, em primeiro lugar, o estímulo ao empreendimento e o patrocínio direto por Alfredo Mesquita; em segundo, o patronato intelectual de Mário de Andrade, que publicou no primeiro número do periódico o texto "Elegia de abril" ${ }^{12}$. Em oposição, a revista Contorno se abre com um texto de um dos membros do grupo, Juan José Sebreli, cujo título explicita o afastamento radical em relação à geração anterior: "Los 'martinfierristas': su tiempo y el nuestro".

Para explicar tais diferenças, devemos questionar inicialmente os padrões de relacionamento entre críticos e escritores nas duas tradições intelectuais. Apesar de complexas e variadas segundo os momentos e os casos, deve-se notar que, na Argentina, desde o final do século XIX, boa parte dos que se dedicaram à crítica literária provinha da $\mathrm{FFyL}$ da UBA, que proporcionava desde seu surgimento um importante canal de ascensão social e de ingresso às atividades intelectuais aos imigrantes e filhos de imigrantes. Relaciona-se a esse fato a forte tensão que polarizava os escritores oriundos das camadas altas e os críticos recrutados nos grupos emergentes. No Brasil, o enraizamento acadêmico da crítica literária foi posterior e não havia diferenças sociais e culturais significativas entre críticos e escritores, ambos recrutados, praticamente, nos mesmos meios sociais e formados, a maioria, nas faculdades de direito. Em tal direção, Clima era o berço da primeira geração de críticos acadêmicos - ironicamente não oriundos do curso de Letras -, que, não obstante, compartilhavam com seus antecessores literatos e críticos o mesmo habitus social e cultural. Além disso, ingressavam como críticos (de literatura, cinema, teatro e arte) num meio cultural que já valorizava em boa medida a crítica como um gênero literário destacado. Por conta disso, a ruptura que realizaram ao propor uma dicção mais especializada e bem-informada aos estudos literários não implicava um afastamento tão profundo em relação à geração anterior ${ }^{13}$, mas sim uma renovação dos instrumentos analíticos e dos métodos que os aproximavam de uma atitude científica.

Passemos, agora, a uma comparação mais detalhada entre as experiências de Clima Contorno, aproximadas por reunirem grupos de estudantes depois 
destacados como críticos extremamente inovadores nas cenas culturais nas quais estavam imersos, vinculados por laços de amizade constituídos no meio universitário e pelo fato de se fazerem afirmar por meio de revistas culturais. Cabe assinalar, também, o fato de Clima e Contorno terem sido editadas no final de regimes autoritários e populistas, o que indica que nos dois casos havia também em jogo condicionantes políticos.

$\mathrm{O}$ dois grupos formaram-se no interior da universidade, mas Clima em uma recém-criada e em cursos novos, enquanto Contorno numa já consolidada e num curso que detinha tradiçôes disciplinares constituídas, embora atravessasse um período de crise derivada das transformaçóes impostas pelo peronismo no ensino superior do país. A relação dos contornistas com a universidade era conflituosa e ambivalente, a dos membros de Clima muito mais satisfatória. Por isso mesmo, se é possível reconhecer um programa de atuação nas declarações ou nas entrelinhas dos textos redigidos nesta última, ele era derivado em grande parte do impacto direto exercido pelos docentes estrangeiros que impuseram modalidades de trabalho mais sistemáticas e exigentes. Tais experiências moldariam, também, novas formas de identidade intelectual, reivindicadas em oposição às anteriores, menos profissionalizadas e mais dispersas. Não propuseram, entretanto, um questionamento radical dos parâmetros mais substantivos que haviam guiado os críticos e os historiadores da literatura brasileira até então. Nesse ponto, devemos marcar uma diferença entre as duas revistas: Contorno propôs uma dessacralização da literatura argentina; questionou o cânone estabelecido, deslocando o eixo de reconhecimento para escritores até aquele momento desprestigiados, principalmente Roberto Arlt. No interior da crítica mesma, voltaram-se contra as tradiçôes teóricas que haviam embasado a escola de Amado Alonso, questionando o pressuposto da autonomia do fato literário ao assumirem uma perspectiva sociológica e política na análise literária. Em tais frentes, os contornistas debateram-se com as gerações anteriores, especialmente com a que havia emergido nos anos de 1920 com as vanguardas e reunida na revista Sur posteriormente. Esta seria a marca dos trabalhos mais importantes que os membros do grupo de Contorno publicaram nos anos de 1960, nos quais a história da literatura argentina é reconstruída a partir das dinâmicas próprias às esferas social e política. Tais operaçôes foram condicionadas pela forte politização da vida intelectual argentina durante o peronismo e após este, bem como pela polarização do mundo literário à qual nos referimos - criollos/ imigrantes, escritores/críticos. 
Essas diferenças devem ser pensadas, também, à luz da composição social dos grupos. O grupo Clima era mais homogêneo e quase todos os seus integrantes tinham origem elevada. Certo declínio social e o reordenamento político derivado da Revolução de 1930 condicionaram as escolhas não usuais que fizeram, canalizadas para os cursos de filosofia ou ciências sociais. A orientação esquerdizante da maioria dos membros também teria determinado tais opções e a formação do grupo na universidade, vinculado por relações afetivas e intelectuais de longa duração futura. Quanto às relações de gênero, houve precedência dos homens, mas participação importante, embora menos visível, das mulheres (nas tarefas de edição da revista, sobretudo). A revista orientaria direta ou indiretamente a carreira profissional ulterior dos membros mais destacados do grupo tanto na universidade como no cenário cultural mais amplo, dinamizado pelo crescimento da cidade de São Paulo e pelos efeitos indiretos da Segunda Guerra Mundial (imigração de intelectuais e artistas europeus). Como já foi sugerido, a afinidade social e política com a geração de escritores egressos do modernismo paulista teria favorecido uma relação de maior continuidade com esse movimento, apesar do distanciamento propiciado pela formação científica recebida na universidade. O grupo de Contorno era heterogêneo socialmente e alguns de seus membros tinham origem desfavorável, refletindo a abertura da universidade argentina durante o peronismo. Isso explica, possivelmente, por que as relaçôes de amizade formadas na universidade e fortalecidas durante o tempo de existência da revista não sobreviveriam por muito tempo. Além disso, houve desde o início divisões internas, condicionadas pela origem social. A assimetria de gênero era talvez mais pronunciada ainda do que em Clima, levando-se em conta que a porcentagem de mulheres no corpo discente da FFyL era de aproximadamente 75\% (cf. Germani, 1956). Apenas uma mulher, Adelaida Gigli, que se casaria com David Viñas, participou da direção da revista. Dos aproximadamente trinta colaboradores de Contorno, apenas três foram mulheres (além da acima citada, Regina Gibaja, Ana Goutman) e sua participação se restringiu a poucos artigos e resenhas de livros. A heterogeneidade do grupo e a origem imigrante de muitos deles esteve na base da atitude contestatória que encamparam.

Espelhada na biografia de Adolfo Prieto, a de Antonio Candido revela-se muito menos acidentada e tortuosa, principalmente em função das vantagens derivadas de sua origem social elevada e das características gerais do campo em que atuou. Não obstante, em função das circunstâncias nas quais se desenvolveu sua carreira profissional, tensōes de ordens diversas - literatura/ 
sociologia, crítica de rodapé (impressionista)/crítica acadêmica (científica), militância/neutralidade política, crítica estética/crítica sociológica - implicaram mudanças de rota e ambiguidades perceptíveis no desenrolar de sua obra, que devem ser levadas em conta para se obter uma visão nuançada de sua trajetória. Sobretudo, sua carreira profissional esteve por muito tempo indefinida entre a sociologia e a crítica literária, e essa tensão implicou distintas soluções de compromisso ao longo do tempo. Comparativamente, as alternativas mais favoráveis e variáveis com as quais se deparou introduziram dificuldades nada desprezíveis, superadas em definitivo apenas em seus escritos de maturidade.

Nasceu em 1918. Seu pai, um médico, e sua mãe descenderam de famílias tradicionais do Rio de Janeiro e tiveram acesso privilegiado à cultura própria dos círculos intelectualizados das elites cariocas. Em função de tais circunstâncias, Antonio Candido obteve educação elevada desde criança. Sua iniciação literária foi precoce, mas adquiriu formação intelectual sistemática, principalmente no curso de ciências sociais da FFCL-USP (1939-1941), em especial sob a batuta de professores da missão francesa, como o filósofo Jean Maugüé e o sociólogo Roger Bastide. O clima de radicalização política posterior a 1930 (segundo depoimentos concedidos em várias oportunidades) o levou a optar por esse curso e a associar toda sua vida ulterior à militância de esquerda, que condicionou mais sua produção intelectual voltada à imprensa do que aquela derivada mais diretamente da atividade universitária ${ }^{14}$. Do grupo Clima fazia parte Gilda de Moraes Rocha (posteriormente Gilda Rocha de Mello e Souza), com quem se casou. Essa aliança matrimonial foi decisiva, servindo de lastro às carreiras de ambos, apesar de ter impulsionado mais a ele. Em 1942, assumiu o cargo de primeiro assistente de Fernando de Azevedo, na Cadeira de Sociologia II, na qual permaneceu até 1958. Naquele mesmo ano, projetado pela recepção favorável dos textos que publicou em Clima, passou a escrever semanalmente na Folha da Manhã, ingressando no círculo prestigioso dos críticos que escreviam para os grandes jornais de São Paulo e do Rio de Janeiro.

Desde meados do século XX, enfraquecido o ciclo das grandes histórias da literatura brasileira - Silvio Romero, José Veríssimo e Ronald de Carvalho -, a esfera própria ao exercício da crítica literária eram os jornais, e assumir um coluna fixa em um deles era uma modalidade de profissionalização do trabalho intelectual e um sinal de distinção inequívoco $^{15}$. Destacavam-se em torno dos anos de 1930, as figuras de Agripino Grieco (O Jornal, RJ), Sergio Milliet (O Estado de São Paulo, SP), Álvaro
14. De tal maneira, as condições vigentes em cada uma dessas instâncias, imprensa e universidade, condicionaram maior ou menor aproximação à política em seus escritos (cf. artigo de Ramassote neste Dossiê). Deve-se notar que na "crítica de rodapé" era comum o crítico expressar sua orientaçāo política (cf. Bolle, 1979).

15. Sussekind (1993) contextualiza o desenvolvimento da crítica literária brasileira, desde as primeiras décadas do século $\mathrm{XX}$, por meio da oposição entre a "crítica de rodapé" (predominante até a metade do século, aproximadamente) e a crítica universitária (progressivamente legitimada). Antonio Candido (também Afrânio Coutinho) moveu-se de uma para outra, encarnando essa transição e as disputas que as opunham. Outro trabalho importante e precursor sobre a "crítica de rodapé", centrado na figura de Álvaro Lins, é Bolle (1979). 
Lins (Correio da Manhã, RJ), Mário de Andrade (Diário Nacional, SP; Diário de Notícias, RJ), Octávio de Faria (O Jornal, RJ), Alceu Amoroso Lima (O Jornal, RJ), entre outras. Ao ingressar nessa arena, Antonio Candido legitimou-se rapidamente por meio de uma dicção mais rigorosa que lhe permitiu distanciar-se do "impressionismo" predominante, sem, no entanto, assumir uma atitude explicitamente científica. No artigo de abertura de seu rodapé "Notas de crítica literária", na Folha da Manhã, Antonio Candido defende uma atitude literária no exercício da crítica:

Há, evidentemente, uma coisa básica no trabalho crítico, que não pertence à metafísica nem à moral do nosso ofício, pois, que é uma qualidade pessoal. Quero referir-me à penetração. Sem ela, sem essa capacidade, elementar para o crítico, de mergulhar na obra e intuir os seus valores próprios, não há explicação possível - isto é, não há crítica. No princípio, portanto, coloca-se um dado psicológico, o que vem mostrar que a crítica parte e se alimenta de condiçôes personalíssimas, as quais será escusado querer fugir. Não há, portanto, coisa alguma que se possa chamar de "crítica científica" - a menos que não se entenda por tal coisa a critica dos trabalhos da ciência. Entendida como transformação da crítica em ciência, não passa de um dos muitos pedantismos criados pela pretensão dos homens de letras" (Candido, 2002, p. 24).

16. Prova disso é o convite de Alvaro Lins, o crítico mais consagrado do momento, feito a Antonio Candido em 1947 para que escrevesse a apresentação da quinta série do seu Jornal de Crítica (cf. Pontes, 1998).

17. Cabe citar: "Com efeito, um dos maiores perigos para os estudos literários é esquecer esta verdade fundamental: haja o que houver e seja como for, em literatura a importância maior deve caber à obra. A literatura é um conjunto de obras, não de fatores, nem de autores." (Candido, 1988, p.103)
Os anos em que escreveu semanalmente para os jornais Folha da Ma-

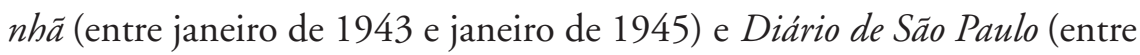
setembro de 1945 e fevereiro de 1947) foram decisivos para afirmar sua reputação como crítico $^{16}$, ao mesmo tempo em que lecionava sociologia na USP, caminhos paralelos e conflitantes que, diante da oportunidade aberta pelo concurso de 1945 para a Cadeira de Literatura Brasileira da USP para o qual se apresentou, poderiam ter alterado o curso de sua trajetória, encurtando sua permanência na sociologia (no caso de vitória).

A derrota de Antonio Candido nesse concurso (vencido por quem era então professor interino da Cadeira, Souza Lima) ocorreu apesar do seu desempenho excelente, que pode ser dimensionado ainda hoje pela leitura de Introdução ao método crítico de Silvio Romero. Essa tese (e o tema), aliás, lhe permitiria definir o contorno da perspectiva metodológica que iria nortear seus estudos posteriores, mas também o de seu grupo, a partir da década de 1960. Nessa direção, adere à posição de T. S. Eliot e afirma a autonomia relativa $\mathrm{da}$ obra literária ${ }^{17}$, para, em seguida, tomando como contraponto o "cientificismo" de Silvio Romero, aproximar-se de uma perspectiva "científica": 
Hoje só podemos conceber como científica a crítica que se esforça por adotar um método literário científico, um método específico, baseado nos seus recursos internos. Estabelecimento de fontes, de textos, de influências; pesquisa de obras auxiliares, análise interna e externa, estudo da repercussão; análise de constantes formais, das analogias, do ritmo da criação: esta seria a crítica científica, a ciência da literatura (Candido, 1988, p.110).

Dois anos depois do concurso, Antonio Candido afastou-se dos jornais e iniciou uma fase mais concentrada, dedicada ao ensino e à pesquisa sociológica na universidade - isso se explica também pela mudança do regime de trabalho dos "professores assistentes", que passou de tempo parcial para integral - e à preparação de seus dois principais trabalhos: a tese Os parceiros do Rio Bonito, defendida em 1954 e publicada em 1964, e A formação da literatura brasileira, publicado em 1959.

Em relação à Formação, não havia dúvida a respeito da intenção do autor de inscrever-se na linhagem dos grandes ensaios de interpretação do Brasil, mas o livro sobre o mundo caipira não foi compreendido nessa chave. Este se afastaria dessa tradição por seu objeto aparentemente restrito e o fato de ser um trabalho acadêmico. Algo destoava em Os parceiros, entretanto, em relação à grande maioria das teses defendidas na USP na mesma época.

$\mathrm{O}$ texto menos carregado e a utilização discreta das ferramentas teóricas tomadas da sociologia e da antropologia na construção de seu argumento distanciavam-no do cientificismo vigente. A interpretação não era neutra, mas sim diretamente interessada nas soluções políticas dos problemas sociais diagnosticados. Além disso, a reconstrução histórica realizada na primeira parte da tese, visando recuperar o processo de formação da sociedade caipira paulista, também a aproximava do ensaísmo brasileiro. Antonio Candido enfrentou pelo avesso o processo amplo de nossa formação histórica e social, privilegiando o agricultor pobre e a pequena propriedade rural em sua análise.

Desse ponto de vista, recuperou o papel desempenhado por esse sujeito nomeado nas diversas regiōes do país como matuto, tabaréu, caboclo, sertanejo -, menosprezado pela maioria dos autores que haviam estudado o processo de formação da sociedade brasileira. Certo pessimismo permeava sua conclusão: diante da modernização capitalista em curso, haveria uma crise dos meios de subsistência do caipira que poderia levar ao seu desaparecimento. $\mathrm{O}$ autor defendia a realização de uma reforma agrária que deveria levar em conta sua realidade social específica, radicalizando a posição encampada anteriormente por autores como Euclides da Cunha e Emílio Willems (cf. Jackson, 2002) ${ }^{18}$.
18. Os comentários sobre $O s$ parceiros estão baseados na sua edição como livro. Heloisa Pontes (1998) discutiu as diferenças entre a tese e o livro. No segundo, a dimensão política é reforçada, sobretudo, pela proposta de realização da reforma agrária na conclusão do trabalho. 
Como dois gêmeos distintos, o que está explícito na Formação, esconde-se em Os parceiros e vice-versa. A intenção de dialogar com a tradição do ensaísmo brasileiro manifesta-se apenas implicitamente neste último. No primeiro, é a relação mais direta com o contexto acadêmico no qual o autor estava inserido que está encoberta. O livro parece descolado das disputas acadêmicas e dos dilemas profissionais enfrentados por seu autor, mas a disputa com a direção dominante da sociologia paulista, que, nesse momento, privilegiava objetos como o desenvolvimento econômico e desvalorizava a cultura como matéria de reflexão, está presente nas entrelinhas. A obra resultou de uma encomenda do editor José de Barros Martins em 1945, que imaginou a realização de uma história da literatura brasileira em dois volumes. Tratava-se, entre outras coisas, de engrossar o coro dos que se indignaram com o resultado do concurso já mencionado.

O pano de fundo histórico mais geral da empreitada seria o do pósguerra e da democratização brasileira (interrompida em 1964), cujo clima geral pode ter influenciado a tese relativamente otimista defendida na obra. Esta afirma a concretização de um movimento histórico iniciado no século XVIII, durante o Arcadismo, e concluído no final do XIX, por meio do Romantismo. Nesses dois séculos, a literatura brasileira teria progressivamente se autonomizado da portuguesa, fato comprovado, segundo o autor, pelo surgimento de um escritor tão sofisticado como Machado de Assis, equiparável aos mestres do Romantismo e do Realismo europeus.

A noção de "sistema literário" é central na argumentação desenvolvida na Formação e remete à dimensão social e histórica da literatura. Uma pista que pode ser explorada diz respeito à definição de religião construída por Durkheim ([1912] 2003). O sociólogo francês considerava as religiōes como fatos sociais e as definia como "sistemas", ou seja, como totalidades formadas por partes interdependentes, as crenças e os ritos, compartilhados por grupos sociais determinados: igrejas. Ao estudar a literatura brasileira como sistema, o crítico a enxergava como fato social, ao menos quando vista à distância, objetivada no conjunto de obras produzidas num período de tempo relativamente largo.

Mas a Antonio Candido interessava, também, a possibilidade do julgamento estético e a defesa da "autonomia relativa" do texto literário. A literatura é definida nesse momento como um "sistema de obras ligadas por denominadores comuns". A configuração progressiva do sistema dependeria ainda da existência de uma tradição intelectual lentamente constituída e continuamente alterada. Em seu esquema, as obras figuram em primeiro 
plano, completando os vértices do triângulo, os "denominadores comuns" autores e público. Não obstante, na Formação o enquadramento sociológico e histórico define o ponto de vista geral por meio do qual as obras são selecionadas e interpretadas.

A forma do livro permite uma leitura completa e, também, a concentração nos ensaios relativamente autônomos que o compõem. Trata-se de uma solução que enquadra os escritores na perspectiva histórica e sociológica, sem negligenciar a intenção propriamente crítica de julgar as obras e os autores de maneira individualizada. Nesse caso, os instrumentos mobilizados na interpretação variam em função da obra em foco, método - entendido como uma atitude adequada à apreensão do objeto literário - designado posteriormente por Antonio Candido como "crítica de vertentes". Em certos casos, a pesquisa deveria apoiar-se no estudo dos condicionantes sociais ou psíquicos envolvidos na "estruturação" do texto literário. Em outros, a análise poderia prescindir dessas dimensões e mover-se apenas no interior do texto, visando esclarecer as lógicas envolvidas em sua organização formal.

Essa seria a orientação geral das análises realizadas na Formação e, sobretudo, em escritos posteriores do autor. Mais do que isso, trata-se de um aspecto central do programa de pesquisas que Antonio Candido iria liderar nas décadas seguintes. Pouco antes da publicação do livro, surgiria nova possibilidade que lhe permitiria superar os dilemas ligados à sua identidade profissional, concretizando um itinerário pessoal que tinha como horizonte a transferência para a área de Letras, por meio do convite para lecionar na Faculdade de Filosofia de Assis, na qual permaneceu entre 1958 e 1961. O passo definitivo nessa direção seria dado com sua indicação para assumir a Cadeira de Teoria Literária e Literatura Comparada da FFCL-USP, em 1961 ${ }^{19}$. Contudo, antes disso, a possibilidade de prosseguir na sociologia estava de alguma maneira prevista, e isso se pode deduzir não apenas da tese defendida, que comprovava sua enorme competência como sociólogo, mas também da armação sociológica de Formação. Neste livro, aliás, percebe-se a influência indireta de Roger Bastide, que ministrou um curso sobre sociologia da arte no início da década de 1940, que resultaria na publicação de Arte e sociedade em 1945.

Vencido o dilema profissional, uma solução analítica se impôs progressivamente, reconhecível sobretudo em estudos como "Estrutura e função do Caramuru" (1961), "De cortiço a cortiço" $(2002)^{20}$ e "Dialética da malandragem” (1970) e nomeada pelo autor como redução estrutural, que consiste em revelar a maneira pela qual os elementos exteriores ao texto são reelaborados como forma literária. Outro aspecto a ser considerado a respeito dessa "mi-
19. Sobre a passagem por Assis e as negociações a respeito da criação da Cadeira de Teoria Literária e Literatura Comparada na USP, ver Ramassote (2006).

20. Esse texto tem duas versôes anteriores (uma publicada em 1974 e outra em 1975), cuja matriz foi publicada em Candido (1993a). A esse respeito ver Dantas (2002). 
21. Um esforço quase simultâneo e na mesma direção foi empreendido por Afrânio Coutinho no Rio de Janeiro, mais explícito no combate ao "impressionismo", orientado pela incorporação do New Criticism e pela defesa do rigor científico e da análise estética nos estudos literários. Ele dirigiu a obra coletiva $A$ literatura no Brasil, militou na imprensa e publicou alguns livros programáticos nos anos de 1950. A disputa com Antonio Candido pode ser apreendida na polêmica que moveu depois da publicação de Formação, questionando a exclusão do barroco nesse livro, bandeira que seria retomada décadas depois por Haroldo de Campos. Antonio Candido não reagiu aos ataques de Afranio Coutinho. Uma ótima reconstrução desse debate encontra-se em Rivron (2005). Sobre a posição de Haroldo de Campos, ver o texto de Moura neste Dossiê. gração institucional" relaciona-se com o fato de, a partir desse momento, Antonio Candido assumir explicitamente a liderança de um programa coletivo de pesquisas, que lhe permitiu ampliar o impacto de sua obra. Ele iria - com a ajuda de seus discípulos (entre os quais Roberto Schwarz, Walnice Nogueira Galvão e Davi Arrigucci Jr.) e de maneira mais flexível do que Florestan Fernandes fizera na sociologia - fixar um novo e mais exigente padrão de trabalho intelectual na crítica literária brasileira. Nessa direção, a Formação constituiuse como o núcleo das formulações teóricas e interpretativas que iriam nortear os trabalhos posteriores do autor e de seu grupo, tornando a crítica literária uma especialidade acadêmica no interior das ciências humanas ${ }^{21}$.

Peça central no conjunto da obra de Antonio Candido, a Formação relaciona-se com a maioria de seus escritos anteriores e posteriores, que devem ser mencionados para que tenhamos uma ideia mais completa de sua trajetória, dos temas que percorreu e dos desenvolvimentos teóricos que proporcionou, não restritos à literatura brasileira. Brigada ligeira de 1945 e $O$ observador literário de 1959 reúnem textos publicados pelo crítico em jornais nas décadas de 1940 e 1950. Tese e antitese de 1964, Literatura e sociedade de 1965, Vários escritos de 1970, A educação pela noite de 1987 e $O$ discurso e a cidade de 1993 percorrem um itinerário cada vez mais sofisticado, do ponto de vista das soluçôes interpretativas sugeridas, orientadas pela ambição de realizar estudos "propriamente dialéticos" sobre os textos literários.

Como vimos, portanto, duas vertentes analíticas interagem na construção do argumento da Formação: uma focada na estruturação do texto literário (pressupondo sua autonomia relativa), outra na configuração da literatura como sistema (mobilizando diretamente a perspectiva sociológica). Essa dupla orientação, estética e sociológica, constituiria, desde que articuladas as dimensões, uma análise propriamente dialética no entender do autor, por esclarecer no mesmo passo a realidade interna ao texto e a relação de interdependência com o meio social circundante. Tal perspectiva constituiu também o programa teórico de seu grupo, permitindo, por meio da ênfase em um dos polos (os exemplos de Roberto Schwarz e Davi Arrigucci são típicos), assimilar certa "heterodoxia" no conjunto de trabalhos realizado pela equipe.

\section{IV}

A comparação das trajetórias de Adolfo Prieto e de Antonio Candido revela aspectos curiosos. O crítico brasileiro começou sua carreira acadêmica nas ciências sociais, lecionando sociologia na USP entre 1942 e 1958. A 
incorporação dos instrumentos analíticos dessa disciplina em sua obra de crítica deu-se, portanto, de maneira convencional, ao contrário de Adolfo Prieto, que se formou e lecionou em Letras, adquirindo familiaridade com a sociologia apenas como autodidata. De certa forma, percorreram caminhos invertidos: Antonio Candido transitando da sociologia para a crítica, Adolfo Prieto da crítica para a sociologia. Além disso, diferentemente do brasileiro, em nenhum momento de sua carreira Prieto escreveu para os jornais, afirmando-se exclusivamente como crítico acadêmico.

Essa última diferença é reveladora das modalidades da estruturação do espaço da crítica literária em cada país. No caso argentino, desde o final do século XIX, a universidade foi um ponto de referência decisivo, especialmente o curso de Letras da FFyL da UBA, sobretudo depois da missão estrangeira centralizada na figura de Amado Alonso nos anos de 1930. No caso brasileiro, os jornais ocuparam, comparativamente, esse lugar até meados dos anos de 1950. Certamente, a imprensa diária tinha, também, importância na Argentina, mas o caso do La Nación sugere sua especificidade. O suplemento cultural desse jornal foi dirigido por longo tempo (entre 1931 e 1955) pelo escritor Eduardo Mallea e vocalizava a perspectiva dos próprios literatos.

De todo modo, Antonio Candido transitou (e realizou a passagem) nos dois principais suportes institucionais da crítica brasileira do século $\mathrm{XX}$, o jornal, até meados dos anos de 1960, e a universidade, a partir dessa última data, construindo por meio deles uma identidade bifronte. Se a primeira dessas fases foi condicionada pela herança social e cultural familiar, sobretudo a segunda explica-se por sua experiência universitária, que inscreveu nele disposições típicas do trabalho acadêmico. Deve-se notar que as incorporou nas ciências sociais e não nas Letras. A montagem de seu grupo nos anos de 1960 espelhou-se nos projetos anteriores de Donal Pierson e Florestan Fernandes na sociologia.

Diferentemente, Adolfo Prieto não dispunha de quase nenhum cacife herdado de sua família e isso condicionou suas escolhas. A opção decidida pela carreira acadêmica, desde que concluiu a graduação, foi uma forma de superar essa desvantagem. Contudo, o projeto acadêmico que pôde realizar até o final dos anos de 1960 enfrentou dois fortes oponentes: os próprios literatos (seu livro sobre Borges é emblemático dessa disputa) e a tradição já estabelecida da crítica acadêmica. Ao contrário, Antonio Candido deparou -se com uma situação diferente, porque, se não havia até os anos de 1960 uma tradição acadêmica forte na crítica literária brasileira, ele teve que impor seu projeto acadêmico em relação à crítica tradicional dos jornais. 
Por fim, se a comparação desses itinerários revela a existência de um grau desigual de reconhecimento intelectual obtido por cada um deles, tal diferença deve ser entendida, também, em função da estrutura dos campos intelectuais nos quais estavam inscritos (mais especificamente, da força detida pela crítica literária em relação à literatura) e das posições que os autores ocuparam no interior de cada sistema acadêmico: Adolfo Prieto na periferia, Antonio Candido no centro.

\section{Referências Bibliográficas}

Barrenechea, Ana María. (1995-1996), "Amado Alonso en el Instituto de Filología de la Argentina”, Cauce: Revista de Filología y Didáctica, 18-19: 95-106.

\& Lois, Élida. (1989), "El exilio y la investigación lingüística en la Argentina”. Cuadernos Hispanoamericanos, 473-474: 81-91.

Bolle, Adélia Bezerra de Menezes. (1979), A obra crítica de Álvaro Lins e sua função histórica. Petrópolis, Vozes.

Borello, Rodolfo A. (1967), "Adolfo Prieto: literatura y sociedad en la Argentina". Cuadernos Hispanoamericanos, 214: 133-146.

Candido, Antonio. (1987). Os parceiros do Rio Bonito. São Paulo, Duas Cidades. . (1988), O método crítico de Silvio Romero. 1a edição 1945. São Paulo, Edusp. . (1993a). O discurso e a cidade. São Paulo, Duas Cidades. . (1993b), Formação da literatura brasileira. Belo Horizonte/Rio de Janeiro, Itatiaia. (org.). (2002), Textos de intervenção. São Paulo, Editora 34.

Correas, Carlos. (2007), La operación Masotta: cuando la muerte también fracasa. Buenos Aires, Interzona.

Coutinho, Afrânio (org.). (1986), A literatura no Brasil. Rio de Janeiro/Niterói, José Olympio/Universidade Federal Fluminense.

Dantas, Vinícius. (2002), Textos de intervenção. São Paulo, Editora 34.

Durkheim, Émile. (2003), As formas elementares da vida religiosa. 1ª edição 1912. São Paulo, Martins Fontes.

Germani, Gino. (1956), "Informe preliminar del Instituto de Sociología sobre las encuestas entre estudiantes universitarios". Centro, 12: 34-46.

KING, John. (1989), Sur: estudio de la revista argentina y de su papel en el desarrollo de una cultura 1931-1970. México DF, Fondo de Cultura Económica.

MannheIm, Karl. (1972), Liberdade, poder e planificação democrática. $1^{a}$ edição 1951. São Paulo, Mestre Jou.

Mangone, Carlos \& Warley, Jorge. (1984), Universidad y peronismo (1946-1955). Buenos Aires, Ceal. 
Miceli, Sergio. (2009), "Mário de Andrade: a invenção do moderno intelectual brasileiro”. In: Botelho, André \& SChwarcz, Lilia Moritz (orgs.). Um enigma chamado Brasil. São Paulo, Companhia das Letras, v. 1, pp. 160-173.

Peixoto, Fernanda Áreas. (1989), "Franceses e norte-americanos nas ciências sociais brasileiras (1930-1960)”. In: Miceli, Sergio (org.). História das ciências sociais no Brasil. São Paulo, Vértice/Idesp/Finep, v. 1, 477-532.

Perosio, Graciela \& Rivarola, Nannina. (1981), "Ricardo Rojas: primer profesor de literatura argentina”. In: ZAPETTI, Suzane (dir.). Historia de la literatura argentina. Buenos Aires, Ceal, pp. 217-240.

Pontes, Heloisa. (1998), Destinos mistos. São Paulo, Companhia das Letras. (2011), Intérpretes da metrópole. São Paulo, Edusp.

Prieto, Adolfo. (1952). "Nota sobre Sábato". Centro, 4: 10-13.

. (1953a), "En la cima del Monte Ararat: bosquejo dramático". Centro, 5: 37-45.

(1953b), "Hacia una biografía de Sarmiento". Centro, 6: 3-5.

(1953c), "A propósito de Los Idolos". Contorno, 1: 5-29.

(1953c), "Borges, el ensayo crítico". Centro, 7: 9-19.

. (1954), Borges y la nueva generación, Buenos Aires, Letras Universitarias.

(1956a), Sociología del público argentino. Buenos Aires, Leviatán.

(1956b), "Peronismo y neutralidad". Contorno, 7/8: 150-153. In: (dir.).

(1959), Proyección del rosismo en la literatura argentina. Rosario, Facultad de Filosofía y Letras, Instituto de Letras, Universidad Nacional del Litoral.

. (1962), La literatura autobiográfica argentina. Rosario, Facultad de Filosofía

y Letras, Instituto de Letras, Universidad Nacional del Litoral.

(1963), Encuesta: la crítica literaria en la Argentina. Rosario, Facultad de

Filosofía y Letras, Instituto de Letras, Universidad Nacional del Litoral.

. (1964), Antología de Boedo y Florida. Córdoba, Universidad Nacional de Córdoba.

. (1968), El periódico Martín Fierro. Buenos Aires, Galerna.

. (1968), Literatura y subdesarrollo. Rosario, Editorial Biblioteca.

. (1968), Diccionario básico de literatura argentina. Buenos Aires, Ceal.

. (1969), Estudios de literatura argentina. Buenos Aires, Galerna.

. (1982), "Literatura/crítica/enseñanza de la literatura: reportaje a Adolfo Prieto".

Punto de Vista, 16 (5): 7-9.

(1988), El discurso criollista en la formación de la Argentina moderna. Buenos

Aires, Sudamericana.

Sebreli, Juan José. (1987), Las señales de la memoria. Buenos Aires, Sudamericana.

SusseKInd, Flora. (1993), Papéis colados. Rio de Janeiro, Editora da UFRJ.

Rivron, Vassili. (2005), Enracinement de la littérature et anoblissement de la musique populaire. Tese de doutorado. Paris, École des Hautes Études en Sciences Sociales. 


\section{Resumo}

\section{Crítica literária e sociologia no Brasil e na Argentina}

Ainda que os processos de modernização da crítica literária no Brasil e na Argentina se inscrevam em tradições intelectuais e organizaçôes acadêmicas distintas, nos dois casos, e quase ao mesmo tempo, a crítica literária renovou-se por meio da relação estabelecida com a sociologia. Nesse sentido, duas trajetórias intelectuais, as de Adolfo Prieto e Antonio Candido, e dois empreendimentos culturais, as revistas Contorno (1953-1959) e Clima (1941-1944), são examinados. Entretanto, se nas duas experiências a renovação da crítica seguiu um caminho análogo, somente no Brasil ela se impôs como atividade desenvolvida no interior da universidade e como instância reconhecida de arbitragem da produção literária nas décadas de 1950 e 1960. Em outros termos, a consagração de Antonio Candido na cena cultural brasileira não pode ser comparada com a que alcançou Adolfo Prieto (ou qualquer outro crítico nesse período) na Argentina. Por quê? Nossa hipótese correlaciona a legitimação da crítica à perda de centralidade da literatura no mundo cultural.

Palavras-chave: Campo intelectual; Tradições intelectuais; Organizaçôes acadêmicas; Sociologia; Crítica literária.

\section{Abstract}

\section{Literary criticism and sociology in Brazil and Argentina}

In Argentina and Brazil the modernization of literary criticism in the 1950s and 60s developed in the context of different intellectual traditions and academic organizations. However in both countries, and almost at the same time, literary criticism was renewed through its contact with sociology. To analyze the relationship between these two academic disciplines, this article examines two intellectual trajectories - those of Adolfo

Texto recebido e aprovado em $30 / 7 / 2011$

Alejandro Blanco é membro do Programa de História Intelectual da Universidade Nacional de Quilmes e pesquisador do Conselho Nacional de Investigações Científicas e Técnicas (Conicet). É autor de Razón y modernidad: Gino Germani y la sociología em la Argentina (Buenos Aires, Siglo XXI, 2006). E-mail: <ablanco@ unq.edu.br>.

Luiz Carlos Jackson é professor do Departamento de Sociologia da USP. E-mail: <ljackson@ usp.br>. Prieto and Antonio Candido - and two cultural magazines - Contorno (1953-1959) and Clima (1941-1944). But although the renewal of literary criticism followed similar paths in both countries, only in Brazil was university-based criticism fully recognized as the foremost intellectual authority over the literary production during the period. In other words, the consolidation of Antonio Candido on the Brazilian cultural scene had no real equivalent in Argentina where neither Adolfo Prieto or any other critic acquired a similar standing. Why? This article explores a possible answer to this question, focusing on the correlation between the consolidation of literary criticism and the decline of the centrality of literature in the cultural world.

Keywords: Field of Knowledge; Intellectual traditions; Academic organizations; Sociology; Literary criticism. 